Abstract G257(P) Table 1 Free text comments from DCH(UK) training course and pilot examination

\begin{tabular}{|c|c|}
\hline \multirow{7}{*}{$\begin{array}{l}\text { The Best aspects of the course and } \\
\text { pilot were }\end{array}$} & $\begin{array}{l}\text { The friendly nature of the examiners } \\
\text { and their courteous manner }\end{array}$ \\
\hline & $\begin{array}{l}\text { Very systematic training, effective for } \\
\text { everybody }\end{array}$ \\
\hline & $\begin{array}{l}\text { Instilling in the care-provider, } \\
\text { compassion and empathy for the } \\
\text { patient }\end{array}$ \\
\hline & Extensive teaching \\
\hline & $\begin{array}{l}\text { Conveying the simple but effective } \\
\text { message, that practice makes perfect }\end{array}$ \\
\hline & $\begin{array}{l}\text { Making us realise there is a human } \\
\text { being in distress at the end of our } \\
\text { stethoscope and not just a subject }\end{array}$ \\
\hline & $\begin{array}{l}\text { "Empathetic dealing" with patients was } \\
\text { highlighted (In India, I did not have this } \\
\text { kind of teaching) }\end{array}$ \\
\hline \multirow{5}{*}{$\begin{array}{l}\text { Suggestions to improve the course } \\
\text { and pilot }\end{array}$} & $\begin{array}{l}\text { Each session should have more time } \\
\text { and more than one case per session }\end{array}$ \\
\hline & \begin{tabular}{|l|} 
On-line lecture series \\
\end{tabular} \\
\hline & Everything was excellent \\
\hline & Should be a 3-4 day course \\
\hline & \begin{tabular}{|l|} 
Make it a 5 day training programme \\
\end{tabular} \\
\hline \multirow{6}{*}{ Further comments } & $\begin{array}{l}\text { An approach to integrate knowledge, } \\
\text { skills and human consideration in } \\
\text { order to improve child health delivery. }\end{array}$ \\
\hline & \begin{tabular}{|l|} 
It was an amazing learning experience! \\
\end{tabular} \\
\hline & $\begin{array}{l}\text { Such training sessions at least once a } \\
\text { month. }\end{array}$ \\
\hline & $\begin{array}{l}\text { A very impressive programme, needs } \\
\text { to be repeated } \\
\end{array}$ \\
\hline & $\begin{array}{l}\text { Was a wonderful learning experience } \\
\text { So useful! }\end{array}$ \\
\hline & $\begin{array}{l}\text { An excellent programme to } \\
\text { acknowledge ones weaknesses and } \\
\text { ways to improve! }\end{array}$ \\
\hline
\end{tabular}

Methods A retrospective review of the PICU admission records and patient medical notes was undertaken for all patients admitted to the PICU from 1st November 2011 until 31st October 2012. Patient information was anonymised and key data was extracted including basic demographics, history of presenting complaint, investigations, management and outcome on the PICU.

Results The PICU had 10 beds, 7 ventilators and 1 haemodialysis machine. There was a shortage of staff with only 1 doctor and 2 nurses at night. Routine investigations were available although microbiology culture was rarely performed.

407 patients were admitted with the majority being infants (range 0-16 years). The furthest distance travelled was $907 \mathrm{Km}$ for a child with lead poisoning. Most patients were admitted for less than 5 days. The peak admission period was during the rainy season which corresponds to the peak incidence of dengue. 64 patients $(17.5 \%)$ presented with dengue shock syndrome or dengue haemorrhagic fever.

The principle reasons for admission included status epilepticus (26.5\%); pneumonia (20\%); dengue (17.5\%); multi-organ failure (14.2\%); septicaemic shock (11.7\%); and encephalitis (9.5\%). Other important reasons for admission were meningitis; gastroenteritis; post-measles complications; diphtheria; snake bite; Beriberi (including Wernicke's encephalopathy); tetanus; rabies; malaria; late haemorrhagic disease of the newborn; malnutrition; tuberculosis; HIV; and poisoning (organophosphates; traditional medicine). All patients with a viper bite died of complications including shock, acute renal failure and pulmonary haemorrhage. The majority of patients with diphtheria were managed with a tracheostomy. Overall mortality on the PICU was $34 \%$.
Conclusions This study provides a unique insight into the local disease burden, resources available and challenges faced in providing paediatric intensive care. The relatively high incidence of vaccine preventable diseases is of particular concern. Key priorities include support for the development of nurse and doctor training; staff retention; evidence-based guidelines; data management including follow-up; referral pathways; access to routine investigations; and a reliable supply of essential medications and equipment.

\section{G259(P) A SYSTEMATIC REVIEW OF HEALTH WORKER-LED INTERVENTIONS TO REDUCE MORTALITY IN LOW BIRTH WEIGHT NEONATES IN LOW AND MIDDLE-INCOME INSTITUTIONAL SETTINGS}

${ }^{1}$ E Kesler, ${ }^{1} \mathrm{~A}$ Costello, ${ }^{1} \mathrm{M}$ Heys, ${ }^{2} \mathrm{~K}$ Azad. ${ }^{1}$ Institute for Global Health, University College London, London, UK; ${ }^{2}$ Perinatal Care Project, BIRDEM General Hospital, Dhaka, Bangladesh

\subsection{6/archdischild-2015-308599.252}

Aim The majority of the 3.3 million annual neonatal deaths worldwide occur because proven and simple interventions dependent upon skilled human resources are not implemented. $60-80 \%$ of these deaths occur in low birth weight (LBW) neonates less than $2.5 \mathrm{~kg}$, with $96.5 \%$ of the 20 million LBW neonates being born in the developing world.

The aim of this research is to carry out the first systematic literature review on health worker-led interventions to reduce mortality in LBW neonates in institutional settings in low and middle-income (LMIC) countries.

Methods We conducted a systematic review of studies meeting our inclusion and exclusion criteria until October 2014 (Figure 1). We searched Pubmed/MEDLINE, Popline, and Cochrane databases utilising a combination of the search terms "low birth weight" or "small for gestational age" and "mortality" and "intervention". We included all studies of health worker led facility-based postnatal interventions in LMIC that assessed

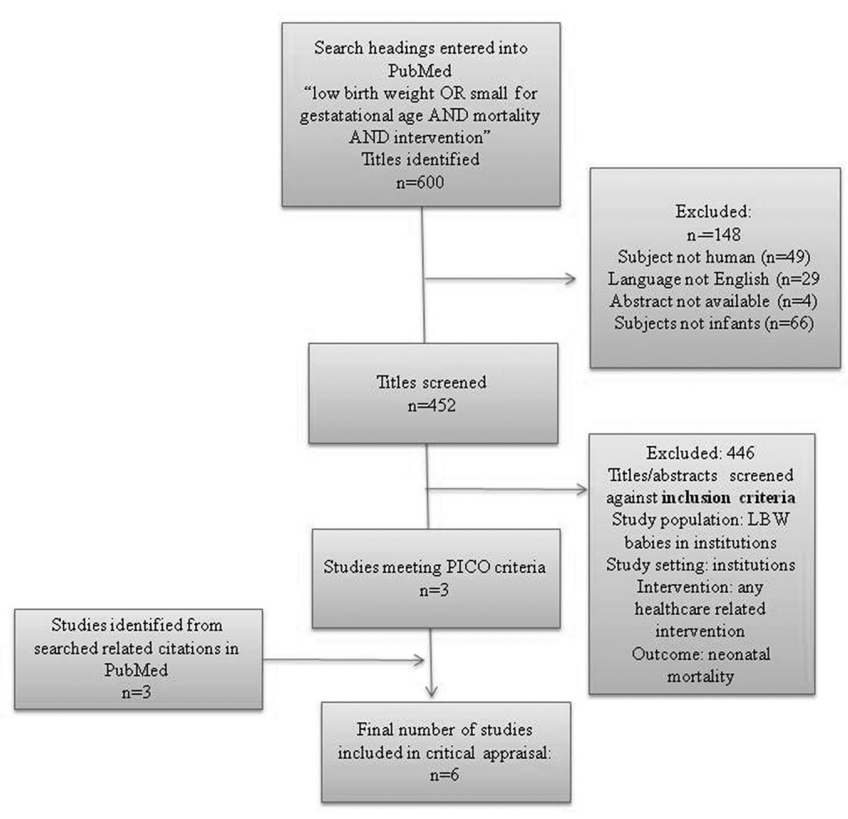

Abstract G259(P) Figure 1 
Abstract G259(P) Table 1 Summary of studies reviewed

\begin{tabular}{|c|c|c|c|c|c|c|}
\hline Authors & Type of study & Subjects & Country, setting location & Objective & Interventions & Outcomes \\
\hline $\begin{array}{l}\text { Agarwal, R. } \\
\text { et. al, } 2007\end{array}$ & $\begin{array}{l}\text { Before and } \\
\text { after }\end{array}$ & $\begin{array}{l}7938 \text { live births before } \\
\text { with } 282 \text { infants }<1500 \mathrm{~g} \\
\text { and } 74<1000 \mathrm{~g}, 7311 \text { live } \\
\text { births after with } 262 \\
<1500 \mathrm{~g} \text { and } 66<1000 \mathrm{~g} \text {. }\end{array}$ & $\begin{array}{l}\text { India, low resource } \\
\text { obstetric teaching } \\
\text { hospital }\end{array}$ & $\begin{array}{l}\text { To evaluate impact of } \\
\text { simple interventions on } \\
\text { neonatal mortality. }\end{array}$ & $\begin{array}{l}\text { Package included: } \\
\text { rational admissions } \\
\text { and early discharge, } \\
\text { maternal involvement, } \\
\text { asepsis routines, } \\
\text { enteral feeding, } \\
\text { protocol-based } \\
\text { management, rational } \\
\text { antibiotics and nurse } \\
\text { training. }\end{array}$ & $\begin{array}{l}\text { NMR declined during the } \\
\text { intervention period as } \\
\text { compared to control period } \\
\text { ( } 20.3 \text { versus } 29.3 \text { per } \\
1000 \text { live births; relative } \\
\text { risk } 0.69,95 \% \text { confidence } \\
\text { interval (CI) } 0.57 \text { to } 0.85 \text { ). }\end{array}$ \\
\hline $\begin{array}{l}\text { Arif \& Arif, } \\
1999\end{array}$ & $\begin{array}{l}\text { Prospective } \\
\text { matched } \\
\text { case control } \\
\text { study }\end{array}$ & $\begin{array}{l}361 \text { LBW (151 case; } \\
211 \text { control) }\end{array}$ & $\begin{array}{l}\text { Pakistan, urban } \\
\text { hospital }\end{array}$ & $\begin{array}{l}\text { To randomize LBW } \\
\text { babies to care } \\
\text { inside an incubator } \\
\text { by nurses or } \\
\text { care by mother at bedside }\end{array}$ & $\begin{array}{l}\text { Care in an incubator } \\
\text { by nurse or care by } \\
\text { mother at mother's } \\
\text { bedside }\end{array}$ & $\begin{array}{l}\text { Mortality rate decreased } \\
\text { by } 57 \% \text { when infant's } \\
\text { were cared for by mothers, } \\
p<.001\end{array}$ \\
\hline $\begin{array}{l}\text { Conde-Agudelo, } \\
\text { A., Diaz-Rossello, } \\
\text { J., } 2014\end{array}$ & $\begin{array}{l}\text { Systematic } \\
\text { review- } 18 \text { RCT }\end{array}$ & 2571 LBW infants & $\begin{array}{l}13 \text { hospitals in LMIC } \\
\text { and } 5 \text { hospitals in } \\
\text { high income countries }\end{array}$ & $\begin{array}{l}\text { To ascertain whether or not } \\
\text { there is evidence to support } \\
\text { the use of KMC in LBW infants } \\
\text { instead of conventional care }\end{array}$ & $\begin{array}{l}\text { Kangaroo mother care } \\
\text { with mother or caregiver }\end{array}$ & $\begin{array}{l}\text { Overall, KMC was } \\
\text { associated with a } \\
\text { statistically significant } \\
\text { reduction in the risk of } \\
\text { mortality at discharge or } \\
40-41 \text { weeks' } \\
\text { postmenstrual age } \\
\text { (3.2\% vs } 5.3 \% \text {; typical } \\
\text { RR } 0.60,95 \% \\
\text { Cl } 0.39 \text { to } 0.92 \text { ) }\end{array}$ \\
\hline $\begin{array}{l}\text { Msemo, G. } \\
\text { et. al, } 2013\end{array}$ & $\begin{array}{l}\text { Before and } \\
\text { after }\end{array}$ & $\begin{array}{l}1000 \text { LBW infants before } \\
\text { and 7,423 LBW after }\end{array}$ & $\begin{array}{l}\text { Three major referral } \\
\text { hospitals in Tanzania, } \\
4 \text { regional hospitals, } \\
1 \text { district hospital }\end{array}$ & $\begin{array}{l}\text { To assess if a new education } \\
\text { program to improve delivery } \\
\text { room stabilization and } \\
\text { resuscitation can decrease } \\
\text { early neonatal death in LBW } \\
\text { and non LBW infants }\end{array}$ & $\begin{array}{l}\text { Helping Babies } \\
\text { Breathe-simple } \\
\text { interventions to improve } \\
\text { delivery room stabilization } \\
\text { and resuscitation }\end{array}$ & $\begin{array}{l}\text { NMR decreased from } \\
61 \text { per } 1,000 \text { live births } \\
\text { to } 29 \text { per } 1,000 \text { live births, } \\
\text { RR } 0.48 ; 95 \% \text { Cl } 0.35-0.6 \text {, } \\
P<.0001\end{array}$ \\
\hline $\begin{array}{l}\text { Mufti, P., } \\
\text { Setna, F. \& } \\
\text { Nazir, K., } \\
2006\end{array}$ & $\begin{array}{l}\text { Before and } \\
\text { after }\end{array}$ & $\begin{array}{l}2498 \text { LBW babies } \\
\text { (971-term, } 1527 \text { preterm) }\end{array}$ & $\begin{array}{l}\text { Karachi, Pakistan, } \\
\text { large teaching hospital }\end{array}$ & $\begin{array}{l}\text { To improve newborn care and } \\
\text { survival rates of LBW babies } \\
\text { through the training of medical } \\
\text { and nursing staff }\end{array}$ & $\begin{array}{l}\text { Training of medical and } \\
\text { nursing staff including } \\
\text { neonatal resuscitation }\end{array}$ & $\begin{array}{l}\text { The NMR decreased } \\
\text { from } 22.4 \text { to } 12.3 \text { per } \\
1,000 \text { live births. Early } \\
\text { NMR was used or death } \\
\text { of a live born infant } \\
\text { over } 500 \mathrm{~g} \text { in the first } \\
7 \text { days of life. }\end{array}$ \\
\hline $\begin{array}{l}\text { Van Der Mei, } \\
1994\end{array}$ & $\begin{array}{l}\text { Non-controlled } \\
\text { descriptive study }\end{array}$ & 567 LBW infants & $\begin{array}{l}\text { Agogo Hospital, } \\
\text { Ashanti region in } \\
\text { Ghana }\end{array}$ & $\begin{array}{l}\text { To establish the survival rate } \\
\text { in the neonatal period with } \\
\text { the scale up of neonatal care }\end{array}$ & $\begin{array}{l}\text { Simple staff training } \\
\text { program and inclusion } \\
\text { of mothers in the } \\
\text { provision of newborn } \\
\text { care }\end{array}$ & $\begin{array}{l}\text { The mortality rate was } \\
26.8 \text { per } 1,000 \text { live births, } \\
\text { the researchers felt this was } \\
\text { a favorable outcome with } \\
\text { small changes in care } \\
\text { provision }\end{array}$ \\
\hline
\end{tabular}

Abbreviations used: NMR- neonatal mortality rate, LBW- low birth weight, KMC- kangaroo mother care

the outcome of neonatal mortality in LBW infants. We excluded articles with abstracts not available, articles that were not in English, and research with subjects not human or subjects not infants.

Results We identified six studies reporting LBW neonatal mortality outcomes for health worker led interventions or a package of interventions in institutional settings in LMIC (Table 1). We employed the Hierarchy of Evidence framework, which evaluates health care interventions, to rank the strength of research evidence as excellent, good, fair or poor (Table 2). Only one study received an excellent ranking, the systematic review on kangaroo mother care (KMC), which included randomised controlled trials that demonstrated a statistically significant decrease in neonatal mortality rates.

Conclusion The literature review demonstrates the limited evidence on health worker-led facility-based postnatal interventions to decrease mortality in LBW infants. Even where adequate evidence exists for impact of interventions on LBW mortality, for example, KMC, there has yet to be consistent scale-up. Further research is necessary utilising more rigorous methodology to ascertain effectiveness of interventions, as well as to identify cost-effective and sustainable strategies to allow for widespread implementation and dissemination of proven interventions. 